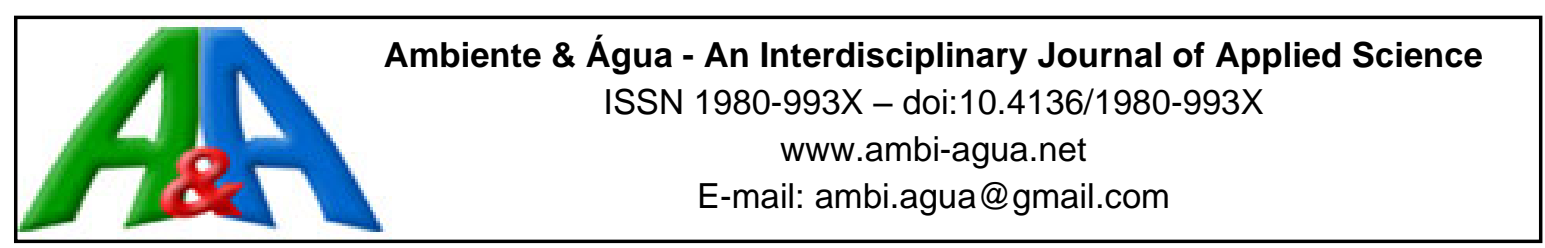

\title{
Superabsorbent polymers in slurry gelling
}

\author{
ARTICLES doi:10.4136/ambi-agua.2533
}

Received: 05 Oct. 2020; Accepted: 09 Nov. 2020

\section{Luiza Fernanda dos Santos Pereira ${ }^{(\text {; }}$ Marcos Roberto Furlan ${ }^{D}$; Paulo Fortes Neto \\ Programa de Pós-Graduação em Ciências Ambientais (PPGCA). Universidade de Taubaté (UNITAU), Estrada Municipal Doutor José Luiz Cembranelli, n5000, CEP: 12081-010, Taubaté, SP, Brazil. \\ E-mail: luiza.ferpereira@gmail.com, furlanagro@gmail.com \\ *Corresponding author. E-mail: paulo.fortes@unitau.br}

\begin{abstract}
Disposal of solid waste in landfills causes negative impacts on the environment, caused by emissions of greenhouse gases and the release of dark-colored leachate. It's composition includes high concentrations of suspended solids, heavy metals, salts and organic compounds. Given the above, this study evaluated the use of superabsorbent polymer in the treatment of leachate. Slurry samples were collected at the Taubate landfill in two seasons to determine electrical conductivity, $\mathrm{pH}$, turbidity, oils and greases. Other samples were submitted to the following treatments: $3.5 \mathrm{~g}$ of polymer with $500 \mathrm{~g}$ of distilled water, and doses of $3.5 ; 7.0 ; 10.5$; $14.0 ; 17.5 ; 21.0 ; 24.5$; and $28.0 \mathrm{~g}$ of polymer with $500 \mathrm{~g}$ of slurry, with 4 repetitions each. Other steps, in sequence, were: transformation of the material into gel (gelation), obtaining the liquid volume of water and slurry, and after $0,12,24,48$ and $72 \mathrm{~h}$, measurements of polymer dehydration were obtained. The efficiency of doses was determined by the volume of leachate remaining after each treatment. Gelation was more efficient in the summer season, a season with lower values of electrical conductivity, $\mathrm{pH}$, suspended solids, and oils and greases. The most efficient doses in gelation were $10.5 \mathrm{~g}$ in summer and $14.0 \mathrm{~g}$ in autumn. In conclusion, superabsorbent polymer can be used in the treatment of leachate because it allows its gelling, but the recommended doses vary with the seasons.
\end{abstract}

Keywords: environmental sciences, leachate, organic waste, urban waste treatment.

\section{Polímeros superabsorventes na gelificação do chorume}

\section{RESUMO}

Disposição de resíduos sólidos em aterros sanitários, devido às emissões de gases do efeito estufa e liberação de lixiviado de coloração escura, provoca impactos negativos no ambiente. Esse lixiviado, denominado por chorume, apresenta composição com altas concentrações de sólidos suspensos, metais pesados, sais e compostos orgânicos. Diante da necessidade de ser tratado, o presente trabalho teve como objetivo avaliar o uso de polímero superabsorvente para essa finalidade. Amostras do chorume foram coletadas no aterro sanitário de Taubaté, em duas estações do ano, para determinar condutividade elétrica, $\mathrm{pH}$, turbidez, óleos e graxas. Outras amostras foram submetidas aos seguintes tratamentos: $3,5 \mathrm{~g}$ de polímero com $500 \mathrm{~g}$ de água destilada, e doses de 3,$5 ; 7,0 ; 10,5 ; 14,0 ; 17,5 ; 21,0 ; 24,5 ;$ e $28,0 \mathrm{~g}$ de polímero com $500 \mathrm{~g}$ de chorume, com 4 repetições cada. Outras etapas, em sequência, foram: transformação do material em gel (gelificação), obtenção do volume líquido da água e do chorume, e após 0, 12, 
24, 48 e 72 h, obtidas medidas de desidratação do polímero. A eficiência das doses foi determinada pelo volume do chorume restante de cada tratamento. A gelificação se mostrou mais eficiente na estação de verão, estação com menores valores de condutividade elétrica, $\mathrm{pH}$, sólidos suspensos, e óleos e graxas. Doses mais eficientes na gelificação foram 10,5 g no verão e $14,0 \mathrm{~g}$ no outono. Como conclusões, polímero superabsorvente pode ser utilizado no tratamento do chorume por possibilitar sua gelificação, e as doses recomendadas variam conforme as estações climáticas.

Palavras-chave: ciências ambientais, lixiviado, resíduo orgânico, tratamento de resíduo urbano.

\section{INTRODUCTION}

The disposal of solid waste in landfills, especially when it is done improperly, causes contamination of surface and underground sources. Even with the negative impacts on the environment, Conte et al. (2018) noted that landfill disposal is still common worldwide. This leachate has high polluting potential, and through runoff or percolation causes soil contamination, surface, and groundwater (Pereira et al., 2013).

Leachate originated from water percolation through decomposing waste presents extremely variable composition, and may contain high concentrations of suspended solids, heavy metals, and organic compounds (Cordeiro et al., 2018). As the amount of leachate generated in a landfill is proportional to the frequency of rainfall, its chemical composition may vary depending on the intensity of rainfall that occurs during the year.

Leachate, like slurry, contains high concentrations of ammoniacal nitrogen, chlorides organic matter and organic compounds that are difficult to break down. Due to its high toxicity, it requires adequate treatments so that its physical, chemical and biological parameters meet the limits established by current legislation (Kawahigashi et al., 2014).

Leachate has been treated using biological processes, such as stabilization ponds or activated sludge; and using membranes, or other processes, such as adsorption, coagulation, and flocculation. However, due to the variable nature of the leachate, there is no consensus regarding which treatment is best (Campos et al., 2013).

One of the possible options for slurry treatment, still little studied, is the use of polymers. The use of these products to treat slurry can be justified by their ability to absorb and retain a large amount of liquid without dissolving. These polymers can have a water absorption of up to 5000 times their own weight in an aqueous medium. However, in solutions with diluted salts, absorption capacity can be reduced to somewhere between 50 to 100 grams of solution for each gram of polymer (Jensen and Hansen, 2001; Assmann, 2013).

The need for studies to verify the feasibility of using superabsorbent polymers in slurry gelation motivated this research. Gelled manure can be used in the composting process for organic waste and, subsequently, be applied in agriculture. It was also important to compare the physical and chemical characteristics of the leachate in the two analyzed seasons to verify if the polymer dose is influenced by this climatic variable.

\section{MATERIAL AND METHODS}

The leachate was obtained from the closed landfill in the municipality of Taubate, located in the Metropolitan Region of Vale do Paraíba and North Coast (RMVPLN), in the State of São Paulo (Figure 1) at the following coordinates: Latitude $-23.018096^{\circ} \mathrm{S}$ e Longitude $-45.506797^{\circ} \mathrm{W}$. In the municipality, according to Fisch (1995), rainy summers and dry winters occur. The hydrological year begins in August and ends in July of the following year. The average annual rainfall is $1.335 \mathrm{~mm}$, and $42 \%$ of the rainfall occurs in the months of December and February (Fisch, 1999). 

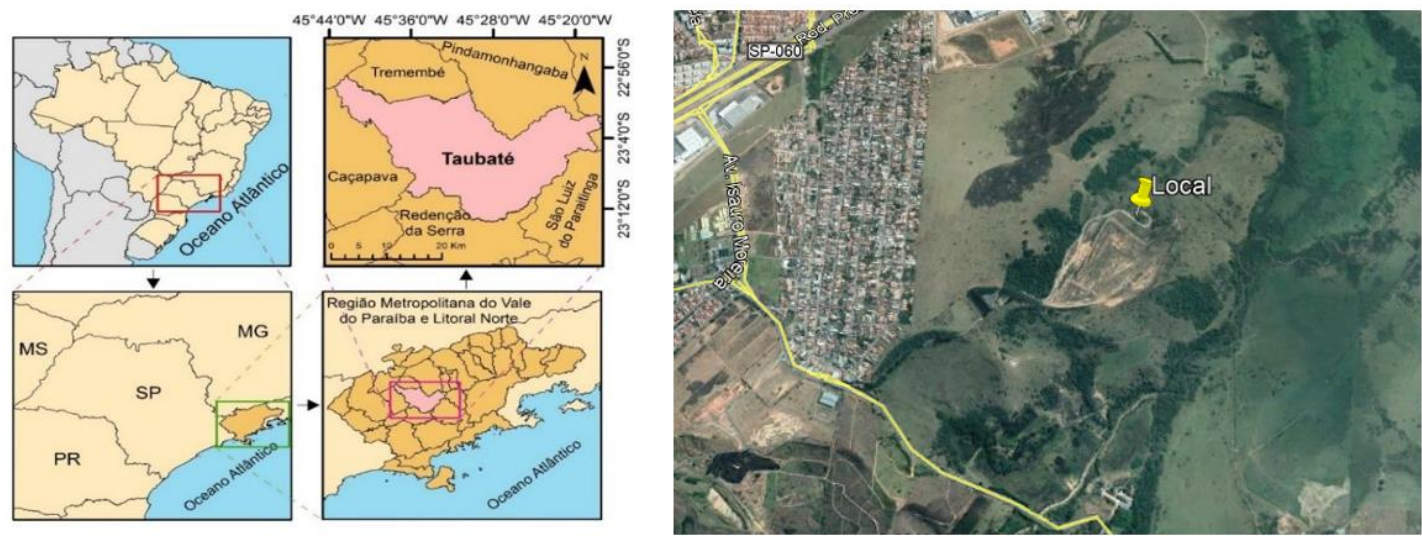

Figure 1. Location of the closed landfill in the municipality of Taubate / SP.

Source: Luiza Fernanda dos Santos Pereira, 2019 and Google Earth, (Google, 2019).

The pluviometric indexes and the temperature of the Summer and Autumn seasons were obtained through the platform of National Institute of Meteorology INMET, by an Automatic Surface Observation Meteorological Station (INMET, 2019). The station, composed of a central memory unit ("data logger") is linked to the sensors of the meteorological parameters, such as precipitation, temperature, and relative humidity, among others. The observed values, minute by minute, are made available per hour.

The Taubaté-A728 station was used, located in the Department of Agriculture Science at UNITAU, at the following coordinates Latitude $-23.041668^{\circ} \mathrm{S}$ ND Longitude $-45.520841^{\circ} \mathrm{W}$. The station is in the same area as the hydrographic basin where the old, deactivated landfill is located, at a distance of $3 \mathrm{~km}$.

The monthly and daily averages of the variable precipitation, temperature and air humidity were obtained during the summer, considering the period of 11/02/2019 to $11 / 03 / 2019$, and in the autumn, from 10/05/2019 to 10/06/2019.

To obtain the physical and chemical composition of the leachate generated in the landfill, samples were collected from the stabilization pond by the third-party company ECOTAUBATÉ during the summer and autumn seasons. Of the $20 \mathrm{~L}$ of slurry collected at each station in the stabilization pond, 2L were sent to the laboratory and submitted to analyses of electrical conductivity, suspended solids, $\mathrm{pH}$, oils and grease and 18L were submitted to the gelling test. Heavy metal analyses were provided by the company ECOTAUBATÉ, and classified as Class IIA (Ecotaubaté, 2019).

To check the gelling capacity of slurry by polymers, water-soluble hydroplan superabsorbent polymer was used, the mixed product of acrylamide and potassium acrylate copolymer, also known as superabsorbent polyacrylamide.

The experimental design for gelling evaluation was completely randomized with four replications, and the following treatments: $3.5 \mathrm{~g}$ of polymer mixed with $500 \mathrm{~g}$ of distilled water, and doses of $3.5 ; 7.0 ; 10.5 ; 14.0 ; 17.5 ; 21.0 ; 24.5 ; \mathrm{e} 28.0 \mathrm{~g}$ of polymer mixed with $500 \mathrm{~g}$ of slurry.

In the slurry gelling test with the superabsorbent polymer, containers with a capacity of $700 \mathrm{~g}$ were used, filled with $500 \mathrm{~g}$ of distilled water and slurry, with the dosages of superabsorbent polymers with the proposed quantities added. The mixture was homogenized to facilitate gelation and then remained at rest for 30 minutes to become hydrogel.

To determine the efficiency of retention of the doses of the superabsorbent polymer, the hydrogel mass and the remaining supernatant were placed for 5 minutes in a $2 \mathrm{~mm}$ mesh sieve to collect the liquid volume. The procedure for measuring polymer degradation was done at the end of $0,12,24,48$ and $72 \mathrm{~h}$.

The results of the efficiency of the dosages of the polymers in the slurry gelling were submitted to analysis of variance (ANOVA) and the differences between the means were evaluated by the Tukey test $(\mathrm{P}<0,05)$. 


\section{RESULTS AND DISCUSSION}

\subsection{Test performed on samples collected in the summer}

In the summer, it was found that the average monthly rainfall was $238,6 \mathrm{~mm}$. The physical and chemical composition of the slurry showed the following characteristics: $\mathrm{pH}=6,7$; oils and greases $=10,9$ mg. $\mathrm{L}^{-1}$; suspended solids $=1,0 \mathrm{mg} \cdot \mathrm{L}^{-1}$ and electrical conductivity $=$ $1,739 \mu \mathrm{s} . \mathrm{cm}^{-1}$. Table 1 shows the results for the masses obtained by mixing distilled water and leachate collected in the summer with different doses of polymers after their gelation in the periods of $0,12,24,48$ and 72 hours.

Table 1. Gelled mass in the period $0,12,24,48$ and 72 hours, under different doses of polymer in the distilled water and in the leachate collected in the summer.

\begin{tabular}{lccccc}
\hline Treatments & \multicolumn{5}{c}{ Gelled product $(\mathbf{g})$} \\
\hline Polymer doses & $\mathbf{0 ~ h}$ & $\mathbf{1 2 ~ h}$ & $\mathbf{2 4} \mathbf{~ h}$ & $\mathbf{4 8 ~ h}$ & $\mathbf{7 2 ~ h}$ \\
\hline A. 3.5 g com 500 g distilled water & $499,940 \mathrm{a}$ & $496,663 \mathrm{a}$ & $492,938 \mathrm{a}$ & $490,623 \mathrm{a}$ & $489,243 \mathrm{~b}$ \\
B. 3.5 g com 500 g slurry & $213,563 \mathrm{c}$ & $207,443 \mathrm{c}$ & $205,070 \mathrm{c}$ & $204,625 \mathrm{~d}$ & $204,600 \mathrm{~d}$ \\
C. 7.0 g com 500 g slurry & $448,528 \mathrm{~b}$ & $432,288 \mathrm{~b}$ & $424,948 \mathrm{~b}$ & $420,850 \mathrm{c}$ & $418,428 \mathrm{c}$ \\
D. 10.5 g com 500 g slurry & $500,000 \mathrm{a}$ & $499,953 \mathrm{a}$ & $499,863 \mathrm{a}$ & $499,743 \mathrm{a}$ & $499,743 \mathrm{a}$ \\
E. 14.0 g com 500 g slurry & $500,000 \mathrm{a}$ & $500,000 \mathrm{a}$ & $500,000 \mathrm{a}$ & $500,000 \mathrm{a}$ & $500,000 \mathrm{a}$ \\
F. 17.5 g com 500 g slurry & $500,000 \mathrm{a}$ & $500,000 \mathrm{a}$ & $500,000 \mathrm{a}$ & $500,000 \mathrm{a}$ & $500,000 \mathrm{a}$ \\
G. 21.0 g com 500 g slurry & $500,000 \mathrm{a}$ & $500,000 \mathrm{a}$ & $500,000 \mathrm{a}$ & $500,000 \mathrm{a}$ & $500,000 \mathrm{a}$ \\
H. 24.5 g com 500 g slurry & $500,000 \mathrm{a}$ & $500,000 \mathrm{a}$ & $500,000 \mathrm{a}$ & $500,000 \mathrm{a}$ & $500,000 \mathrm{a}$ \\
I. 28.0 g com 500 g slurry & $500,000 \mathrm{a}$ & $500,000 \mathrm{a}$ & $500,000 \mathrm{a}$ & $500,000 \mathrm{a}$ & $500,000 \mathrm{a}$ \\
\hline Coefficient of variation & $0.788574 \%$ & $0.703877 \%$ & $0.72673 \%$ & $0.691499 \%$ & $0.676468 \%$ \\
\hline
\end{tabular}

Source: Data from research (2019).

Averages followed by the same letter have no significant difference between them at the level of

$5 \%$ probability by the Tukey test.

According to Table 1, in all the periods evaluated, doses equal to or greater than $14 \mathrm{~g}$ of polymer completely gel the leachate, even shortly after its application in the leachate $(0 \mathrm{~h})$. However, considering the statistical analysis, a $10.5 \mathrm{~g}$ dose does not differ significantly from these treatments.

In the periods from 0 to $48 \mathrm{~h}$, the gelation of the water already occurs with $3.5 \mathrm{~g}$ of polymer, as there was no significant difference compared with doses 10.5 to $28.0 \mathrm{~g}$ of leachate. The lowest value of gelled mass was obtained in the dose $3.5 \mathrm{~g}$ of polymer mixed with $500 \mathrm{~g}$ of slurry, differing significantly from the other treatments.

In all analyses, low values of variation coefficient were observed, which indicates an excellent control of the random variations for the summer season.

The observed gelation occurs because the superabsorbent polymers hydrate is in contact with water, leading to the formation of a swollen polymer gel. Klemm and Sikora (2012) reported that when chemical cross-linking of the polymer's three-dimensional structure comes into contact with water, a process of diffusion of the liquid's molecules into the empty spaces inside the polymeric network occurs, causing the polymer to swell.

\subsection{Test performed on samples collected in autumn}

In the fall, it was found that the monthly rainfall was $93,2 \mathrm{~mm}$. The physical and chemical composition of the manure had the following characteristics: $\mathrm{pH}=7,5$; oils and greases $=$ $32,1 \mathrm{mg} . \mathrm{L}^{-1}$; suspended solids $=1,0 \mathrm{mg} . \mathrm{L}^{-1}$ and electrical conductivity $=5,0 \mu \mathrm{s} . \mathrm{cm}^{-1}$.

Table 2 shows the results for the masses obtained by mixing distilled water and leachate collected in the autumn with different doses of polymers after their gelation in the periods of 0 , $12,24,48$ and 72 hours. 
Table 2. Gelled mass in the period 0,12, 24, 48 and 72 hours, under different doses of polymer in distilled water and slurry, for autumn season.

\begin{tabular}{lcrrrr}
\hline Treatments & \multicolumn{5}{c}{ Gelled product (g) } \\
\hline Polymer doses & $\mathbf{0 ~ h}$ & $\mathbf{1 2 ~ h}$ & $\mathbf{2 4} \mathbf{~ h}$ & $\mathbf{4 8 ~ h}$ & $\mathbf{7 2 ~ h}$ \\
\hline A. 3.5 g com 500 g distilled water & $499,153 \mathrm{a}$ & $497,332 \mathrm{a}$ & $494,447 \mathrm{a}$ & $491,580 \mathrm{a}$ & $489,635 \mathrm{a}$ \\
B. 3.5 g com 500 g slurry & $162,205 \mathrm{~d}$ & $158,152 \mathrm{~d}$ & $157,207 \mathrm{~d}$ & $157,188 \mathrm{~d}$ & $157,188 \mathrm{~d}$ \\
C. 7.0 g com 500 g slurry & $333,184 \mathrm{c}$ & $321,142 \mathrm{c}$ & $315,735 \mathrm{c}$ & $313,469 \mathrm{c}$ & $312,211 \mathrm{c}$ \\
D. 10.5 g com 500 g slurry & $470,843 \mathrm{~b}$ & $462,383 \mathrm{~b}$ & $457,891 \mathrm{~b}$ & $454,310 \mathrm{~b}$ & $451,719 \mathrm{~b}$ \\
E. 14.0 g com 500 g slurry & $497,910 \mathrm{a}$ & $497,790 \mathrm{a}$ & $497,716 \mathrm{a}$ & $497,593 \mathrm{a}$ & $484,767 \mathrm{a}$ \\
F. 17.5 g com 500 g slurry & $499,929 \mathrm{a}$ & $499,929 \mathrm{a}$ & $499,929 \mathrm{a}$ & $499,929 \mathrm{a}$ & $499,929 \mathrm{a}$ \\
G. 21.0 g com 500 g slurry & $500,000 \mathrm{a}$ & $500,000 \mathrm{a}$ & $500,000 \mathrm{a}$ & $500,000 \mathrm{a}$ & $500,000 \mathrm{a}$ \\
H. 24.5 g com 500 g slurry & $500,000 \mathrm{a}$ & $500,000 \mathrm{a}$ & $500,000 \mathrm{a}$ & $500,000 \mathrm{a}$ & $500,000 \mathrm{a}$ \\
I. 28.0 g com 500 g slurry & $500,000 \mathrm{a}$ & $500,000 \mathrm{a}$ & $500,000 \mathrm{a}$ & $500,000 \mathrm{a}$ & $500,000 \mathrm{a}$ \\
\hline Coefficient of variation & $0.368759 \%$ & $0.414237 \%$ & $0.483304 \%$ & $0.485977 \%$ & $1.883162 \%$ \\
\hline
\end{tabular}

Source: Data from research (2019).

Averages followed by the same letter have no significant difference between them at the level of 5\% probability by the Tukey test.

In all evaluation periods in the fall (Table 2), no significant differences $(p<0.05)$ were found by the Tukey Test between the treatments $3.5 \mathrm{~g}$ of polymer mixed with $500 \mathrm{~g}$ of distilled water and the doses of 14.0 to $28.0 \mathrm{~g}$ of polymer mixed with $500 \mathrm{~g}$ of slurry. The lowest value of gelled mass was obtained at a dose of $3.5 \mathrm{~g}$ of polymer mixed with $500 \mathrm{~g}$ of slurry, differing significantly from the other treatments. The variation coefficients, as shown in Table 2, were adequate.

Like the results obtained in the summer, the gelation, verified in most of the tested doses, occurred because the polymer has the capacity to absorb and retain large amounts of water and nutrients (Saad et al., 2009).

Comparing the leachate samples collected in autumn and summer, the differences in the values of oils and greases and electrical conductivity are highlighted, which were, respectively, 10,9 mg.L $\mathrm{L}^{-1}$ (summer) and 32,1 mg.L $\mathrm{L}^{-1}$ (autumn), and 1,739 $\mu \mathrm{s.cm}{ }^{-1}$ (summer) and $5,000 \mu \mathrm{s} . \mathrm{cm}^{-1}$ (autumn).

The results verified in the present study, when the stations are compared, may be associated with the electrical conductivity of the leachate, because with the increase of salts in the solution, the efficiency of the polymer decreases due to the reduction of the absorption capacity caused by the entry of salts that end up occupying the polymer exchange sites (Jensen and Harsen, 2001; Bouchonneau et al., 2010; Assmann, 2013).

The polymer may undergo greater dehydration in the presence of large concentrations of salts, which justify the differences observed. In summer, the total gelling of the slurry occurred at a dose of $10.5 \mathrm{~g}$ of polymer mixed with $500 \mathrm{~g}$ of slurry at 0 hours, while in the fall, a dose of $14.0 \mathrm{~g}$ of polymer mixed with $500 \mathrm{~g}$ of slurry occurred in all periods evaluated.

As in the work of Duarte (2011), it was possible to verify in the present study that the viscosity decreases with the addition of salt; this phenomenon occurs due to the electrostatic spreading promoted by the salt. The polymer gradually becomes a nonionic polymer. The presence of salts thus reduces electrostatic repulsion between the charges in the polymer, limiting the expansion of the macromolecule and, therefore, the viscosity and transparency decrease.

Due to its ability to absorb up to 300 times its mass in water and 100 times its volume, as reported by Saad et al. (2009), the polymer, considering the results of the present work, demonstrates that it can be used for gelling of leachate, and thus facilitate its transport to be used, for example, in composting. Marconato and Franchetti (2002) highlighted that polymers constitute a class of materials with great affinity for water. 


\section{CONCLUSIONS}

Superabsorbent polymer can be used in the treatment of leachate in order to make it gel, and thus facilitate its transport for use in composting.

The chemical composition characteristic of the leachate, which varies according to the season, can change its efficiency in the leachate gelling, but even with the differences observed in dosages, the application of superabsorbent polymer is an alternative for the slurry treatment.

\section{REFERENCES}

ASSMANN, A. Physical properties of concrete modified with superabsorbent polymers. 2013. 213 f. Tese (Doutorado em Engenharia Civil e Ambiental) - Universidade de Stuttgart, Alemanha, 2013.

BOUCHONNEAU, N. et al. Análise da absorção de água em dois polímeros expandidos: desenvolvimento do módulo de flutuabilidade de um mini-robô submarino. Polímeros, v. 20, n. 3, p. 181-187, 2010. http://dx.doi.org/10.1590/s0104-14282010005000032

CAMPOS, J. C.; MACHADO, B. da S.; BLONSKI, M. E. D.; BILA, D. M.; FERREIRA, J. A. Evaluation of coagulation/flocculation process in the landfill leachate treatment at the Municipal Wastewater Treatment Plant. Revista Ambiente \& Água, v. 8, n. 3, p. 1-6, 2013. https://doi.org/10.4136/ambi-agua.1187

CONTE, M. et al. A case study of municipal solid waste landfills impact on air pollution in South Areas of Italy. The Open Atmospheric Science Journal, v. 12, n. 1, 2018. http://dx.doi.org/10.2174/1874282301812010001

CORDEIRO, C. T.; NUNES, R. M.; LANDA, G. G. Diagnóstico da área do antigo lixão do município de Nanuque, Minas Gerais, Brasil. Acta Biologica Brasiliensia, p. 32-50, 2018.

DUARTE, C. M. G. Caracterização químico-física de novos polímeros estabilizantes para formulações da indústria de cosméticos. 2011. 70 f. Dissertação (Mestrado em Química) - Universidade de Coimbra, Portugal, 2011.

INMET. Estação meteorológica de observação de superfície automática. Dados de 2019. Available at: http://www.inmet.gov.br/portal/ Access: 14 Mar. 2020.

ECOTAUBATÉ. Fornecimento de dados sobre a geração de chorume produzido no antigo aterro de Taubaté: documento. Taubaté, 2019.

FISCH, G. Caracterização climática e balanço hídrico de Taubaté (SP). Revista Biociências, v. 1, n. 1, p. 81- 90, 1995.

FISCH, G. Distribuição da precipitação em Taubaté, Vale do Paraíba (SP). Revista Biociências, v. 5, n. 2, p. 7-11, 1999.

GOOGLE. Google Earth website. Available at: http://earth.google.com/ Access: 2019.

KLEMM, A.; SIKORA, K. Superabsorbent polymers in cementitious composites. Construction Materials and Structures, p. 86-91, 2012.

JENSEN, O. M.; HANSEN, P. F. Water-entrained cement-based materials: I. Principles and theoretical background. Cement and concrete research, v. 31, n. 4, p. 647-654, 2001. https://doi.org/10.1016/S0008-8846(01)00463-X 
KAWAHIGASHI, F. et al. Pós-tratamento de lixiviado de aterro sanitário com carvão ativado. Engenharia sanitária e ambiental, v. 19, n. 3, p. 235-244, 2014. http://dx.doi.org/10.1590/S1413-41522014019000000652

MARCONATO, J. C.; FRANCHETTI, S. M. M. Polímeros superabsorventes e as fraldas descartáveis: uma alternativa para o ensino de polímeros. Química Nova na Escola, v. 15, p. 42-44, 2002.

PEREIRA, A. R. et al. Avaliação da qualidade da água superficial na área de influência de um lixão. Revista Ambiente \& Água, v. 8, n. 3, p. 239-246, 2013. http://dx.doi.org/10.4136/ambi-agua.1160

SAAD, J. C. C.; LOPES, J. L. W.; SANTOS, T. A. dos. Manejo hídrico em viveiro e uso de hidrogel na sobrevivência pós-plantio de Eucalyptus urograndis em dois solos diferentes. Engenharia Agrícola, v. 29, n. 3, p. 404-411, 2009. 